\title{
Shifting baselines and the conservation of non-native species
}

\author{
Miguel Clavero \\ Estación Biológica de Doñana - CSIC. Avd. Américo Vespucio s/n, 41092 Sevilla, Spain, email \\ miguelclavero@ebd.csic.es
}

Running head: Introduced species and baseline shifts

\section{Introduction}

The shifting baseline syndrome occurs because humans adapt the notion of healthy ecosystems to the characteristics of contemporaneous environments, either because of an inefficient intergenerational transmission of knowledge or the deformation of personal memories (Pauly 1995; Papworth et al. 2009). In altered systems, the shifting baseline syndrome may lead to constant downgrading of environmental reference conditions (Pauly 1995).

Introductions of non-natives species by humans have occurred for millennia. Cultural traditions tend to embrace newly introduced organisms progressively, by attributing to them the values originally associated with native species (Trigger et al. 2008; Schüttler et al. 2011). This cultural integration represents a form of shifting baseline syndrome, through which the new species are included in the assumed normal or desirable state of natural systems (Speziale et al. 2012). Consequently, if these widely accepted introduced species decline, societies may feel compelled to restore them. For example, the European Habitats Directive mandates the protection of the European mouflon (Ovis orientalis musimon), introduced to Corsica and 
Sardinia (Poplin 1979), and the porcupine (Hystrix cristata), introduced to Italy (Masseti et al. 2010), while in Australia there are initiatives to reintroduce dingoes (Canis lupus dingo) in areas from which the species had been extirpated (Allen \& Fleming 2012)

Already introduced, established species can be threatened by newly introduced ones (e.g. Carpentier et al. 2007). When the former are valued species the shifting baseline syndrome may be manifested in a clear preference toward the species that had been introduced first. These processes are illustrated here with two examples from Spain, showing how societies may promote the control or eradication of introduced species with the aim of conserving previously introduced ones; that is, the aim is to maintain or recover a degraded state of natural systems.

\section{Threat of non-native species to other non-native species}

Crayfish

The white-clawed crayfish (Austropotamobius italicus) was introduced to Spain in the 18th century, probably from northern Italy (Trontelj et al. 2005; Clavero \& Villero 2014). There was no other crayfish species in historical times in the Iberian Peninsula before that moment. Some authors argue that the natural origin of Spanish white-clawed crayfish populations cannot be ruled out (e.g., Matallanas et al. 2013), but their anthropogenic introduction remains the most accepted hypothesis (Chiesa et al. 2011). In any case, there is no doubt that the white-clawed crayfish is an introduced species throughout at least the vast majority of its Spanish range (Clavero \&Villero 2014). In the mid-1970s two North American crayfish species, Pacifastacus leniusculus and Procambarus clarkii, were introduced to Spain and their populations expanded rapidly. Their role as asymptomatic vectors of crayfish plague 
(Aphanomyces astaci) is considered the main cause of white-clawed crayfish decline in Spain; their range has been reduced by around 90\% (Alonso 2011).

The white-clawed crayfish is the focus of several conservation initiatives in Spain, including population reinforcements and stocking of new areas. In contrast, North American crayfish species, after an initial positive reception by Spanish authorities, are now often subjected to population control (Alonso 2011). These management actions implicitly place a reference environmental baseline in the late 1960s, when the range of the white-clawed crayfish reached its maximum and it was the only crayfish species in Spain (Clavero \& Villero 2014).

Minks

The extant range of the European mink (Mustela lutreola) encompasses three isolated areas, the biggest in Russia and the others in the lower Danube and between southwestern France and northern Spain (Maran et al. 2011). Without previous evidence of its presence, the species was first reported in France in 1831 and in Spain in 1955 (Saint-Girons 1994). Genetic patterns observed in this western population, including an almost complete lack of genetic variability, are better explained by human-mediated introduction than by other possible mechanisms (Michaux et al. 2005). Feral American mink (Neovison vison) populations occur in more than 20 European countries. The species was first recorded in Spain and France in the 1970s and is currently established within the range of the European mink in both countries (Bonesi \& Palazón 2007). The two species do not coexist in the long-term because the smaller European mink is excluded by the American mink (Maran et al. 2011).

The European mink has been the focus of several management actions in Spain, including the establishment of a captive breeding program (Maran et al. 2011). The 
American mink is often subjected to population control, although this has not stopped its spread (e.g., Melero et al. 2010).

\section{Conserving non-native species}

Our perception of the native or non-native status of a species and the association of values to it can be conditioned by a short-term vision of biodiversity (Willis \& Birks 2006). Although historical and genetic data provide evidence for the introduced status of white-clawed crayfish and European mink populations in Spain, this information is largely ignored (e.g., white-clawed crayfish are commonly known as "the native crayfish"). Both the crayfish and the mink are the focus of several conservation actions and are clearly preferred over other non-native species that are taxonomically and ecologically similar. These are thus clear examples of a shifting baseline syndrome in the management of introduced species

Individual perceptions of introduced species can depend on personal contact with them (Gozlan et al. 2013). The acceptance of white-clawed crayfish and European mink in Spain is, however, generalized across society, resembling that of species introduced thousands of years ago (Carthey \& Banks 2012). But the spread of crayfish and mink in Spain started just some two centuries and five decades ago, respectively. How long will it take for societies to embrace some of the several current invaders as natives? In the long-term, some of these species can be assimilated as functionally or culturally valuable because of their important roles in ecosystems (Tablado et al. 2010) or their incorporation into cultural traditions (Núñez \& Simberloff 2005; Pfeiffer \& Voeks 2008; J arošík et al. 2011). These social acceptance processes deserve attention from conservation scientists and managers because they may lead to profound shifts in conservation baselines. 
Both white-clawed crayfish (as "A. pallipes") and European mink are globally threatened species (listed as endangered and critically endangered, respectively, on the IUCN Red List) and are listed in Annex II of the European Union Habitats Directive, which forces member states to designate special areas for their conservation. It seems thus appropriate to open a debate in Europe and other management spheres on whether active conservation should focus on non-native species.

The decisions about which species or systems should be prioritized for conservation have a social, rather than purely scientific, base (e.g., Caplat \& Coutts 2011; Chamberlain et al. 2012). Conservation-oriented science must supply useful tools to improve the management of biodiversity and use objective approaches to identify conservation targets. But ultimately the decisions about what should be a conservation priority should be taken by societies. The possibility of devoting conservation efforts to introduced species can be discussed, but this would imply that anthropogenically modified ecosystem states are desirable. Furthermore, the question arises regarding which (if any) should be the introduced species deserving conservation measures. Local or regional values can be important in promoting the conservation of highly appreciated introduced species. But it should be taken into account that those values are dynamic and that this dynamism may drive shifts in environmental baselines. Which non-native species will we be struggling to conserve 100 years from now? 


\section{Acknowledgments}

Comments by J . Calzada, M. Delibes, J . Román,J . L. Tella, and several reviewers improved this work. I had a Ramón y Cajal contract funded by the Spanish Ministry of Science and Innovation.

\section{Literature Cited}

Allen, B. L., \& P. J . S. Fleming, 2012. Reintroducing the dingo: the risk of dingo predation to threatened vertebrates of western New South Wales. Wildlife Research 39: 35-50.

Alonso, F. 2011. Austropotamobius italicus (Faxon, 1914). Pages 651-672 in J . R. Verdú, C. Numa and E. Galante, editors. Atlas y libro rojo de los invertebrados amenazados de España (Especies Vulnerables). Ministerio de Medio Ambiente, Medio Rural y Marino, Madrid.

Bonesi, L., and S. Palazón. 2007. The American mink in Europe: status, impacts, and control. Biological Conservation 134: 470-483

Caplat, P., and S. R. Coutts. 2011. Integrating ecological knowledge, public perception and urgency of action into invasive species management. Environmental Management 48: 878-881

Carpentier, A., R. E. Gozlan, J . Cucherousset, J . M. Paillisson \& L. Marion. 2007. Is topmouth gudgeon Pseudorasbora parva responsible for the decline in sunbleak Leucaspius delineatus populations? J ournal of Fish Biology 71(suppl. D): 274278.

Carthey, A. J . R., and P. B. Banks. 2012. When does an alien become a native species? a vulnerable native mammal recognizes and responds to its long-term alien predator. PLoS one 7: e31804 
Chamberlain, E. C., M. B. Rutherford, and M. L. Gibeau. 2012. Human perspectives and conservation of grizzly bears in Banff National Park, Canada. Conservation Biology 26: 420-431

Chiesa, S., M. Scalici, R. Negrini, G. Gibertini, and F. Nonnis Marzano. 2011. Finescale genetic structure, phylogeny and systematics of threatened crayfish species complex. Molecular Phylogenetics and Evolution 61: 1- 11

Clavero, M., and D. Villero. 2014. Historical ecology and invasion biology: long-term distribution changes of introduced freshwater species. BioScience (in press)

Gozlan, R. E., D. Burnard, D. Andreou, and J. R. Britton. 2013. Understanding the threats posed by non-native species: public vs. conservation managers. PloS one 8: e53200

Jarošík, V., P. Pyšek, and T. Kadlec. 2011. Alien plants in urban nature reserves: from red-list species to future invaders? NeoBiota 10: 27-46

Maran, T., D. Skumatov, S. Palazón, A. Gómez, M. Põdra, A. Saveljev, A. Kranz, R. Libois, and S. Aulagnier. 2011. Mustela lutreola. In IUCN 2012. IUCN Red List of Threatened Species. Version 2012.2. Accessed April 2013

Masseti, M., U. Albarella, and J . D. G. Mazzorin. 2010. The crested porcupine, Hystrix cristata L., 1758, in Italy. Anthropozoologica 45: 27-42.

Matallanas, B., M. D. Ochando, F. Alonso, and C. Callejas. 2013. Phylogeography of the white-clawed crayfish (Austropotamobius italicus) in Spain: inferences from microsatellite markers. Molecular Biology Reports 40:5327-5338.

Melero Y., S. Palazón, L. Bonesi, and J . Gosálbez. 2010. Relative Abundance of culled and not culled American mink populations in Northeast Spain and their potential distribution: are culling campaigns effective? Biological Invasions 12: 3877-3885. 
Michaux, J . R., R. Libois, O. J . Hardy, F. J usty, P. Fournier, A. Kranz, M. Cabria, A. Davison, and R. Rosoux. 2005. Conservation genetics and population history of the threatened European mink Mustela lutreola, with an emphasis on the west European population. Molecular Ecology 14: 2373- 2388.

Nuñez, M. A., and D. Simberloff. 2005. Invasive species and the cultural keystone species concept. Ecology and Society 10: r4.

Papworth, S. K., J . Rist, L. Coad, E. J . Milner-Gulland. 2009. Evidence for shifting baseline syndrome in conservation. Conservation Letters 2: 93- 100.

Pauly, D. 1995. Anecdotes and the shifting baseline syndrome of fisheries. Trends in Ecology and Evolution 10: 430.

Pfeiffer, J . M., and R. A. Voeks. 2008. Biological invasions and biocultural diversity: linking ecological and cultural systems. Environmental Conservation 35: 281293.

Poplin, F. 1979. Origine du mouflon de Corse dans une nouvelle perspective paléontologique: par marronnage. Annales de Génétique et de Séléction Animale 11: $133-143$.

Saint-Girons, M. C. 1994. Wild mink (Mustela lutreola) in Europe. Nature and environment 54. Council of Europe press, Strassbourg.

Schüttler, E., R. Rozzi, and K. J ax. 2011. Towards a societal discourse on invasive species management: a case study of public perceptions of mink and beavers in Cape Horn. J ournal for Nature Conservation 19:175- 184

Speziale, K., S. Lambertucci, M. Carrete, and J . L. Tella. 2012. Dealing with nonnative species: what makes the difference in South America. Biological Invasions 14: 1609-1621 
Tablado, Z., J. L. Tella, J . A. Sánchez-Zapata, and F. Hiraldo. 2010) The paradox of the long-term positive effects of a North American crayfish on a European community of predators. Conservation Biology 24: 1230-1238.

Trigger, D., J . Mulcock, A. Gaynor, and Y. Toussaint. 2008. Ecological restoration, cultural preferences and the negotiation of 'nativeness' in Australia. Geoforum 39: $1273-1283$

Trontelj, P., Y. Machino, and B. Sket. 2005. Phylogenetic and phylogeographic relationships in the crayfish genus Austropotamobius inferred from mitochondrial COI gene sequences. Molecular Phylogenetics and Evolution 34: $212-226$

Willis, K. K., and H. J . B. Birks. 2006. What is natural? The need for a long-term perspective in biodiversity conservation. Science 314: 1261-1265 